\title{
Invitro assessment of native nuclear polyhedrosis virus efficacy for the management of Spodoptera litura reared on artificial diet
}

\author{
Muhammad Bilal Ayyub ${ }^{1 *}$, Ahmad Nawaz ${ }^{1}$, Shah Zaman ${ }^{1}$, Amer Rasul ${ }^{1}$, \\ Tauqir Anwar ${ }^{1}$, Gulzar Ullah' ${ }^{2}$, Faizan Amjad ${ }^{1}$ and Mubashar Iqbal ${ }^{1}$ \\ 1. Department of Entomology, University of Agriculture Faisalabad, 38000-Pakistan \\ 2. Department of Horticulture, University of Agriculture Peshawar, 25000-Pakistan \\ *Corresponding author's email: mbilalayyub@gmail.com \\ Citation \\ Muhammad Bilal Ayyub, Ahmad Nawaz, Shah Zaman, Amer Rasul, Tauqir Anwar, Gulzar Ullah, Faizan Amjad \\ and Mubashar Iqbal. Invitro assessment of native nuclear polyhedrosis virus efficacy for the management of \\ Spodoptera litura reared on artificial diet. Pure and Applied Biology. Vol. 9, Issue 1, pp1077-1084. \\ http://dx.doi.org/10.19045/bspab.2020.90113
}

Received: 28/10/2019 Revised: 31/12/2019

Accepted: 03/01/2020

Online First: 25/01/2020

\section{Abstract}

Microbial based insecticides have great potential for the management of various agricultural insect pests. Present research was conducted to assess the efficacy of indigenous nuclear polyhedrosis virus (NPV) for the management of Spodoptera litura (Fabricius). A field survey was conducted for collection of NPV infected larvae of $S$. litura with specific symptoms. Out of 38 collected NPV infected isolates (larvae) the best isolate showed maximum mortality in $S$. litura larvae in two screening experiments. The selected isolate was given the name V-SpltNPV and was multiplied for further experimentation. The V-SpltNPV identified by Giemsa stain under an inverted microscope. Concentrations of V-SpltNPV were prepared by dilution with distilled water and counted by hemocytometer. Effectiveness of native isolate V-SpltNPV was assessed against $2^{\text {nd }}$, $3^{\text {rd }}$ and $4^{\text {th }}$ and $5^{\text {th }}$ instar $S$. litura larvae on artificial diet in laboratory. Artificial diet pieces were contaminated with various concentrations $\left(1 \times 10^{8}, 1 \times 10^{7}, 1 \times 10^{6}, 1 \times 10^{5}\right.$ and $\left.1 \times 10^{4} \mathrm{OBs} / \mathrm{ml}\right)$ of VSpltNPV and offered to $S$. litura larvae. The highest concentration $\left(1 \times 10^{8} \mathrm{OBs} / \mathrm{ml}\right)$ of V-SpltNPV caused maximum $(68.52 \%)$ mean mortality of $2^{\text {nd }}$ instar larvae while minimum mean mortality $(51.11 \%)$ of $5^{\text {th }}$ instar larvae was occurred by tested concentrations. Conclusively, local isolate if isolated and multiplied can be proved best for the management of several insect pest species.

Keywords: Artificial diet; Biological control; Nuclear polyhedrosis virus; NPV; Spodoptera litura

Introduction

Spodoptera species (Lepidoptera: Noctuidae) contain the insect pests of economically important crops and widely distributed throughout sub-tropical, tropical and the temperate zones [1]. About 30 species of
Spodoptera have been described till now with their presence in six continents around the globe [2]. Their larvae attack on more than 120 different plant species including various vegetables, flowers and weeds etc. $[3,4]$ The main insect pests of genus Spodoptera are 
Spodoptera litura (Fabricius), Spodoptera exigua (Hübner), Spodoptera littoralis (Biosduval) and Spodoptera frugiperda (Federici). The S. litura (Lepidoptera: Noctuidae) is the most important species of Spodoptera genus. It has main economic importance due to higher reproductive potential and attack on verity of agricultural crops. $[5,6]$ The $S$. litura is also known to infest broad range of succulent crops [7]. Its larvae attack on more than 112 plant species from 40 different plant families [8].

Larvae of S. litura have wide host range, which can be important factor for their survival $[9,10]$. Selection of host plants mainly relay on the nutritional differences which are linked with the primary as well as secondary metabolites which are present in those plants [9]. The $S$. litura is mainly a leaf eater as it chew the leaves but also attack on buds, flowers, immature bolls and old leaves. Its larvae prefer to attack on the midrib veins of leaves. In case of severe attack larvae can defoliate the complete plant. Due to severe attack fields of infected crop look like standing sticks [11]. The female of $S$. litura normally lay eggs (1000-2000) in cluster of 200-300 at lower side of the leaf and cover them with abdominal hairs to protect from natural enemies [12]. Incubation of $S$. litura is completed in 4 days in warm weather [5]. The $S$. litura larvae has six instars and complete its period in 16-24 days depending upon host plant and environmental conditions [13]. Pupation occurs inside the soil debris and pupation occur for 8-12 days. The adult remain alive for mostly 4-10 days. Its total life cycle is about 5-6 weeks with 3-4 generations in a year [14]. The $S$. litura also known as cotton leafworm, tropical armyworm, cluster caterpillar, tobacco caterpillar and common cutworm [15]. In ideal conditions, its population increased and move across fields as large masses in search of food, so called as armyworm. Its larvae have ability to cause upto $100 \%$ crop loss.
[16] It is distributed worldwide especially in subcontinant [17]. Various artificial diets have been developed for rearing of Lepidopterous insect pests like S. litura [18]. Mostly artificial diets proved themselves effective for successful rearing of those insects but in some cases there is loss of reproductive potential which ultimately enhance the developmental period and reduced the rate of fecundity [19].

The S. litura is now severe insect pest of Pakistan which attack in various areas of Pakistan [20]. The increase in productions of various succulent crops such as vegetables, cotton, mung bean, soya bean and cabbage provide ideal circumstances to $S$. litura for vigorous reproduction that results in its rapid population increase [21]. Despite the modern technology, few control strategies have been recommended to manage the $S$. litura population [22].

Repeated and irrational chemical insecticide use is causing resistance in various insect pests against those chemical insecticides in many countries [23] including Pakistan. The increase of pesticide use has led to a heavy cost regarding environmental and human health issues [20].

Microbial biopesticides especially virus based pesticides are a strong biological agent of major insect pest due to their safety to nontargeted organism [24]. Among different families of viruses, the Baculoviridae family has been most extensively used as a biopesticide to control the world's most damaging insect pests [25]. Baculoviruses considered as the most intensively studied the insect pathogenic virus [26]. Baculoviruses have about 600 different host insect species to infect, which includes members of different orders such as Lepidoptera, Hymenoptera, and Diptera. Putative members of baculoviruses have been found from Coleoptera, Orthoptera, Neuroptera, Trichoptera, and Thysanura [27]. The pathogenicity level of these viruses against 
targeted pest and their presence varies among different geographic isolates [28].

Propagation or multiplication of nuclearpoly hedrosis virus is mainly done by in vivo and in vitro $[29,30]$. Commonly used technique is in vivo, inn which simply infecting the healthy targeted larvae by NPVs mixed diet and harvest the infected larval population for the virus propagation [31].

Present research was conducted to evaluate the efficacy of native nuclearpolyhedrosis virus isolate against the larvae of $S$. litura which was reared on artificial diet.

\section{Materials and methods}

\section{Rearing of insects}

The larvae of Spodoptera litura (Fabricius) were collected from agricultural fields of university of Agriculture, Faisalabad and brought to the laboratory for rearing under controlled environment (70 $\pm 5 \% \mathrm{RH}, 26 \pm$ $2^{\circ} \mathrm{C}$ Temp, 12:12h light: dark photoperiod) in IPM laboratory, Entomology department, University of Agriculture, Faisalabad. Artificial diet was prepared as previously described [32]. Newly hatched larval population was transferred indivually to plastic vials (3 $\mathrm{cm}$ diameter, $3.2 \mathrm{~cm}$ height) containing artificial diet piece.

Pupae were shifted in plastic jar and kept until adult emergence. The mouth of the jar was tightly covered with muslin cloth. The $10 \%$ honey solution (cotton plug was soaked in honey and placed in jar) was given to adults. Paper strips hanged in the jar for egg laying. Eggs were collected from the paper strip and shifted to a petri dish for hatching. Freshly hatched larvae then again shifted to artificial diet for rearing as described above. More than ten generations of $S$. litura population were reared in the laboratory before the experimentation.

\section{Collection, isolation and identification of NPV infected larvae}

NPV infected larvae with specific symptoms were collected from agriculture fields. After isolation and identification of V-SpltNPV described by [32] V-SpltNPV was propagated in $4^{\text {th }}$ larval instar of $S$. litura by offering them V-SpltNPV contaminated diet and allowed to feed on contaminated diet for 8 days.

Concentrations were prepared after 6 counts under Neubauer hemocytometer [33]. These concentrations were used in the experiments. Various concentrations $\left(1 \times 10^{4}, 1 \times 10^{5}\right.$, $1 \times 10^{6}, 1 \times 10^{7}$ and $\left.1 \times 10^{8} \mathrm{OBs} / \mathrm{ml}\right)$ of $\mathrm{V}$ SpltNPV were prepared by diluting them in distilled water.

\section{Potential assessment of NPV isolates at different dose rates in laboratory conditions}

Efficacy of five concentrations $\left(1 \times 10^{4}\right.$ to $1 \times 10^{8} \mathrm{OBs} / \mathrm{ml}$ ) of $\mathrm{V}-$ Splt NPV were evaluated under laboratory conditions. Artificial diet pieces of $10 \mathrm{~g}$ were cut and prepared concentrations were applied on that pieces with the help of micropipette. The contaminated diet pieces were placed in plastic vials.

Newly molted 30 larvae of $2^{\text {nd }}, 3^{\text {rd }}, 4^{\text {th }}$ and $5^{\text {th }}$ in stars were individually placed in plastic vials containing diet pieces and allowed to feed. For control treatment, diet pieces treated with distilled water were used. All plastic vials were placed in a growth chamber with controlled environment $(70 \pm 5 \% \mathrm{RH}$, $26 \pm 2{ }^{\circ} \mathrm{C}$ Temp, 12:12h light: dark photoperiod). Mortality was recorded after every $48 \mathrm{~h}$ until pupation. (Concentrations repeated 3 times). All experiments/ each treatment was were replicated three times using

\section{Data analysis}

Completely Randomized Design. After the completion of the experiments, corrected mortalities were calculated by Abbott's [34] formula and mortality data was analyzed by using Statistic 8.1 software and means were separated by Tukey's HSD test at $\alpha=5 \%$.

\section{Results and Discussion}

The V-SpltNPV bioassays performed against $2^{\text {nd }}, 3^{\text {rd }}, 4^{\text {th }}$ and $5^{\text {th }}$ instar of $S$. litura larvae 
showed different mean mortalities ranges against various concentrations as $22.68 \%$ to $68.52 \%$ for tested larvae (Fig 1 \& 2). According to the results $2^{\text {nd }}$ instar larvae were more susceptible than the other tested larvae of S. litura. Similarly, $5^{\text {th }}$ instar larvae were most resistant than the other larval instars. Higher mean mortalities $(68.52 \%)$ of $2^{\text {nd }}$ instar larvae of $S$. litura were observed in the bioassay (Fig 1).

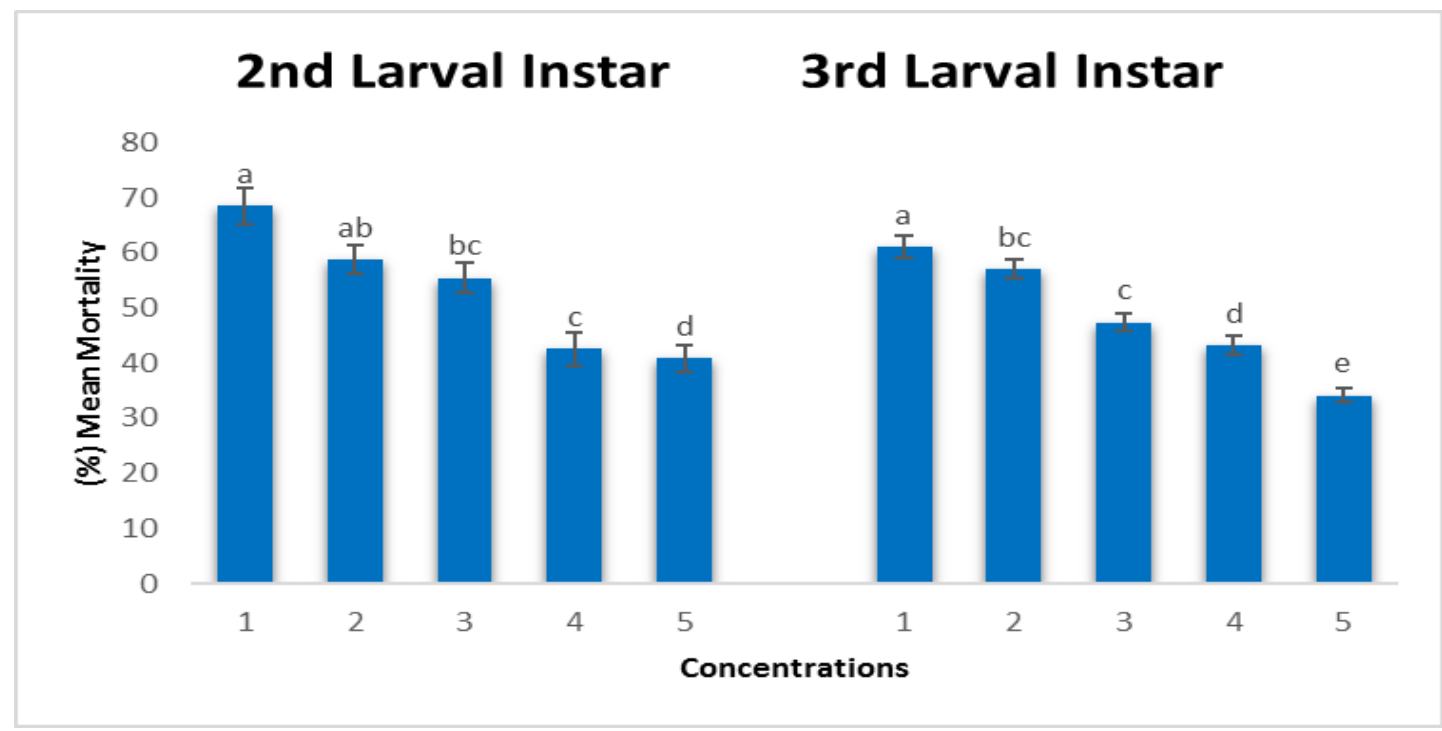

$1 ; 1 \times 10^{8} \mathrm{OBs} / \mathrm{ml}, 2 ; 1 \times 10^{7} \mathrm{OBs} / \mathrm{ml}, 3 ; 1 \times 10^{6} \mathrm{OBs} / \mathrm{ml}$,

$4 ; 1 \times 10^{5} \mathrm{OBs} / \mathrm{ml}, 5 ; 1 \times 10^{4} \mathrm{OBs} / \mathrm{ml}$

Figure 1. Assessment of NPV isolates at various concentrations against $2^{\text {nd }}$ and $3^{\text {rd }}$ instar $S$. litura larvae

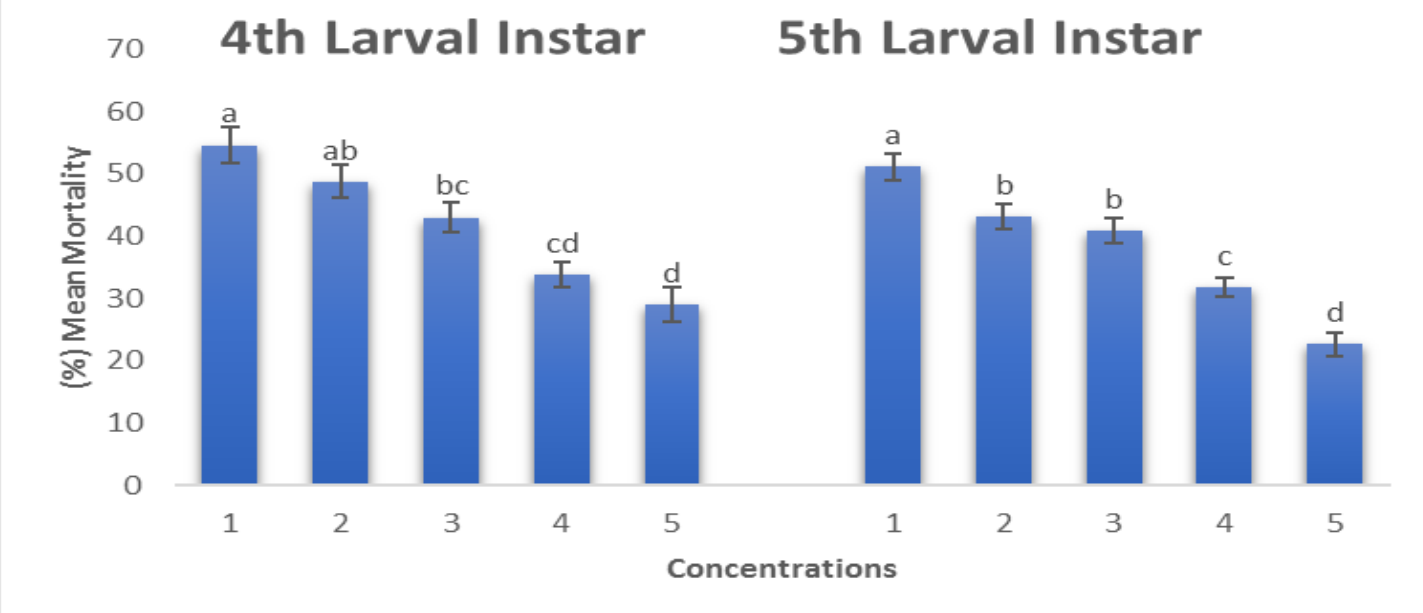

$1 ; 1 \times 10^{8} \mathrm{OBs} / \mathrm{ml}, 2 ; 1 \times 10^{7} \mathrm{OBs} / \mathrm{ml}, 3 ; 1 \times 10^{6} \mathrm{OBs} / \mathrm{ml}$,

4; $1 \times 10^{5} \mathrm{OBs} / \mathrm{ml}, 5 ; 1 \times 10^{4} \mathrm{OBs} / \mathrm{ml}$

Figure 2. Assessment of NPV isolates at various concentrations against $4^{\text {th }}$ and $5^{\text {th }}$ instar $S$. litura larvae 
Mean mortalities were decreasing with increasing the larval age as $3^{\text {rd }}$ instar larvae showed $(61.12 \%), 4^{\text {th }}$ instar larvae resulted $(54.59 \%)$ mean mortality and the $5^{\text {th }}$ instar showed least mean mortality $(51.11 \%$ ) (Fig $2)$. Mean mortalities were increased with increasing the concentrations.

The current outcomes are in line with [35] who recorded $30.55 \%$ to $86.11 \%$ mean mortalities of $2^{\text {nd }}$ instar $S$. litura larvae when exposed to different formulations of $S I N P V$. Furthermore, the recent results are also supported by Monobrullah and Nagata [36] as they suggested increase in the value of $\mathrm{LD}_{50}$ for second to fifth larval instar of $S$. litura showing an increase in resistance against NPV with an increasing larval age. There are number of studies to support current findings [37-40].

Older instars showing resistant to the formulations of V-SpltNPV may be due to the physiological variations which are related to the pupation, resulted resistance development against the process of infection on the older larval instars. Such results were agreed with the findings of [41].

The results are in accordance with [42] that the inverse correlation among susceptibility of insect larvae, associated with an increase in larval biomass with the increase in larval age. Our research in line with the findings of [43] who revealed that the increasing trend in the $\mathrm{LC}_{50}$ values of SpltNPV was observed for second to third larval instar of $S$. litura. Similar results were discussed by [44] who observed the increasing $\mathrm{LC}_{50}$ values of NPV formulation with increasing the larval age of Heliothis punctigera (Wallengren). Similarly, [42] noticed the difference in the values of $\mathrm{LC}_{50}$ among $1^{\text {st }}$ and $5^{\text {th }}$ larval instar of $S$. litura. The value of $\mathrm{LC}_{50}$ was 34000 times higher for the $5^{\text {th }}$ larval instar when compared with $1^{\text {st }}$ larval instar of Mamestra brassicae (Linnaeus), while the $5^{\text {th }}$ and the $6^{\text {th }}$ larval instars were almost at par for the resistant to viral infectivity.
The results may differ with previous findings because it has been also reported that the change in the lethal activity of NPV isolates may depend on the insect population [45] Our findings supported by [47] as they observed considerable differences in the $\mathrm{LD}_{50}$ values between $S$. exigua NPV isolates from Thailand, United States, and Spain. While [47] reported that there was no such difference between the $\mathrm{LD}_{50}$ values of two geographically different NPV isolates of $M$. brassicae, collected from the Germany and Netherlands.

The physiological variations linked with the pupation process might not allowed infection at the lateral developing stage as the old age larvae (10 days) were more resistant to SlNPV formulations. The opportunity of biovirus not getting enough time to multiply the virus or to kill the larvae may not be ruled out. Such observations get support from the results of instars $[42,44]$. In line to our research Milks [39] also noticed a decreasing trend in $\mathrm{LC}_{50}$ values with the decrease in larval age. According to them, for eight day old larvae $\mathrm{LC}_{50}$ value was $1.4 \times 10^{8} \mathrm{PIB} / \mathrm{ml}$ while for two day old larvae of $S$. litura $\mathrm{LC}_{50}$ value was $1 \times 10^{3} \mathrm{PIB} / \mathrm{ml}$. Over all, the results were in accordance with previous studies which indicated the efficacy of experiments and the procedure to execute them in different conditions.

\section{Conclusion}

Conclusively native isolate V-SpltNPV have the ability to manage the $S$. litura population presented in agricultural fields of Pakistan. The V-SpltNPV can be used in integrated manner with other integrated pest management tactics to significantly reduce the use the toxic chemical pesticides.

\section{Authors' contributions}

Conceived and designed the experiments: MB Ayyub \& A Nawaz, Performed the experiments: MB Ayyub, S Zaman \& $\mathrm{T}$ Anwar, Analyzed the data: G Ullah \& M Iqbal, Contributed materials/ analysis/ tools: 
MB Ayyub, A Rasul \& F Amjad, Wrote the paper: MB Ayyub.

\section{Acknowledgement}

The authors highly acknowledged Higher Education Commission (HEC) Pakistan for funding this research project.

\section{References}

1. Venette RC, Hutchison WD \& Andow DA (2000). An in-field screen for early detection and monitoring of insect resistance to Bacillus thuringiensis in transgenic crops. J Eco Entomol 93(4): 1055-1064.

2. Heppner JB (1998). Spodoptera armyworms in Florida (Lepidoptera: Noctuidae). Fla. Department Agric. \& Consumer Services, Division of Plant Industry. Entomol Circular, pp 390: 1-5.

3. Pogue MG (2003). World Spodoptera Database (Lepidoptera: Noctuidae). US Department of Agriculture, Systematics and Entomology Laboratory, Beltsvile, MD

(http://www.sel.barc.usda.gov/lep/spodo ptera.html).

4. Tojo S, Hayakawa $\mathrm{Y} \&$ Phaophan $\mathrm{P}$ (2008). Strains in the common cutworm, Spodoptera litura (Lepidoptera: Noctuidae) with differing host ranges. Appl Entomol Zool 43(4): 491-496.

5. Xue M, Pang YH, Wang HT, Li QL \& Liu TX (2010). Effects of four host plants on biology and food utilization of the cutworm, Spodoptera litura. J Insect Sci 10(1): 22.

6. Zhou Z, Chen Z \& Xu Z (2010). Potential of trap crops for integrated management of the tropical armyworm, Spodoptera litura in tobacco. J Insect Sci 10(1).

7. Skibbe U, Christeller JT, Callaghan PT, Eccles CD \& Laing WA (1996). Visualization of $\mathrm{pH}$ gradients in the larval midgut of Spodoptera litura using 31P-NMR microscopy. J Insect Physiol 42(8): 777-790.
8. Mallikarjuna N, Kranthi KR, Jadhav DR, Kranthi S \& Chandra S (2004). Influence of foliar chemical compounds on the development of Spodoptera litura (Fab.) in interspecific derivatives of groundnut. J of Appl Entomol 128(5): 321-328.

9. Lee KP, Raubenheimer D, Behmer ST \& Simpson SJ (2003). A correlation between macronutrient balancing and insect host-plant range: evidence from the specialist caterpillar Spodoptera exempta (Walker). J Insect Physiol 49(12): 1161-1171.

10. Simpson SJ, Raubenheimer D, Behmer ST, Whitworth A \& Wright GA (2002). A comparison of nutritional regulation in solitarious-and gregarious-phase nymphs of the desert locust Schistocerca gregaria. J Exp Biol 205(1): 121-129.

11. Huque $H$ (1994). Insect pests of fiber crops. Insect pest manag cer cash crop 1:193-260.

12. Rao GR, Wightman JA \& Rao DR (1993). World review of the natural enemies and diseases of Spodoptera litura (F.) (Lepidoptera: Noctuidae). Int J of Trop Inse Sci 14(3): 273-284.

13. Garad, GP, Shivpuje PR \& Bilapate, GG (1984). Life fecundity tables of Spodoptera litura (Prayogo Fabricius) on different hosts. Proceedings: Animal Sci 93(1): 29-33.

14. Qin H, Ye Z, Huang S, Ding J \& Luo R (2004). The correlations of the different host plants with preference level, life duration and survival rate of Spodoptera litura Fabricius. Chin J Eco-Agri 12(2): 40-42.

15. USDA, Pests not known to occur in the United States or of limited distribution, No. 24: Rice cutworm, 1982, pp 1-8.

16. Dhir BC, Mohapatra HK \& Senapati B (1992). Assessment of crop loss in groundnut due to tobacco caterpillar, Spodoptera litura (F.). Indian J Plant Prot 20(2): 215-217. 
17. Kranthi, KR, Jadhav DR, Kranthi S, Wanjari RR Ali SS \& Russell DA (2002). Insecticide resistance in five major insect pests of cotton in India. Crop Prot 21: 449-460.

18. Castane, C \& Zapata R (2005). Rearing the predatory bug Macrolophus caliginosus on a meat based diet. Biol Contr 34: 66-72.

19. Coudron, TA Wittmeyer, J \& Kim Y (2002). Life history and cost analysis for continuous rearing of Podisus maculiventris (Heteroptera: Pentatomidae) on a zoophytophagous artificial diet. J econ Ent 95: 1159-1168.

20. Ahmad M, Arif MI \& Ahmad M (2007). Occurrence of insecticide resistance in field populations of Spodoptera litura (Lepidoptera: Noctuidae) in Pakistan. Crop Prot 26: 809-817.

21. Gao C, Bei Y, Chen T \& Gu X (2004). On factors causing outbreak of Spodoptera litura (Fabricius). Acta Agri Zhejiangensis 16(5): 332-335.

22. Prayogo, $\mathrm{Y}$, Tengkano $\mathrm{W} \&$ Marwoto $\mathrm{D}$ (2005). Prospect of entomo-pathogenic fungus Metarhizium anisopliae to control Spodoptera litura on soybean. $J$ Litbang Pertanian 24: 19-26.

23. Tong H, Su Q, Zhou X \& Bai L (2013). Field resistance of Spodoptera litura (Lepidoptera: Noctuidae) to organophosphates, pyrethroids, carbamates and four newer chemistry insecticides in Hunan. China J Pest Sci 86(3): 599-609.

24. Liu X, Zhang Q, Xu B \& Li J (2006). Effects of Cry1Ac toxin of Bacillus thuringiensis and nuclear polyhedrosis virus of Helicoverpa armigera (Hübner) (Lepidoptera: Noctuidae) on larval mortality and pupation. Pest Manag Sci 62: 729-737.

25. Inceoglu $A B$, Kamita $S G \&$ Hammock BD (2006). Genetically Modified Baculoviruses: A Historical Overview and Future Outlook. Adv Virus Res 68: 323-360.

26. Szewczyk B, Rabalski L, Krol E, Sihler W \& de Souza ML (2009). Baculovirus biopesticides-safe alternative to chemical protection of plants. J Biopest 2: 209-216.

27. Slack J \& Arif BM (2006). The baculoviruses occlusion-derived virus: virion structure and function. Advan Virus Res 69: 99-165.

28. Battu, GS \& Arora R (1996). Genetic diversity of baculoviruses-implications in insect pest management. Biotechnological perspectives in chemical ecology of insects, pp 170-200.

29. Ikonomou, L, Schneider YJ \& Agathos SN (2003). Insect cell culture for industrial production of recombinant proteins. Appl Micro Biotec 62(1): 1-20.

30. Vail PV, Sutter G, Jay DL \& Gough D (1971). Reciprocal infectivity of nuclear polyhedrosis viruses of the cabbage looper and alfalfa looper. J Invert Pathol 17(3): 383-388.

31. Eberle KE, Wennmann, JT, Kleespies RG \& Jehle JA (2012). Basic techniques in insect virology.In Manual Tech. Invertebr. Pathol. (Second Edition), pp $15-74$.

32. Ayyub MB, Nawaz A, Arif MJ \& Amrao $L$ (2019). Individual and combined impact of nuclear polyhedrosis virus and spinosad to control the tropical armyworm, Spodoptera litura (Fabricius) (Lepidoptera: Noctuidae), in cotton in Pakistan. Egypt J Biol Pest Cont 29(1): 67.

33. Cory AD, \& Myers JH (2004). Adaptation in an insect host-plant pathogen interaction. Ecology Letters 7: 632-639.

34. Abbott WS (1925). A method of computing the effectiveness of an insecticide. J Econ Entomol 18: 265267. 
35. Pritha G, Satpute NS Thakare V \& Dadmal SM (2018). Bioassay, crossinfectivity and shelf life studies of Spodoptera litura nuclear polyhedrosis Virus. 6(1): 365-369

36. Monobrullah M \& Nagata M (2000). Effects of larval age on susceptibility of Spodoptera litura (Lepidoptera: Noctuidae) to Spodoptera litura multiple nuclear polyhedrosis virus. The Canad Entomol 132(3): 337-340.

37. Kamala Jayanthi PD (1992). Studies on the microbial and chemical pesticides in the control of Spodoptera litura (Fabricius) (Noctuidae: Lepidoptera). Doctoral dissertation, Andhra Pradesh Agricultural University, Hyderabad.

38. Milks ML, Burnstyn I \& Myers JH (1998). Influence of larval age on the lethal and sub lethal effect of the nuclear polyhedrosis virus of Trichoplusia $n i$ in the cabbage looper. Biol Cont 12: 119126.

39. Trang, T K \& Chaudhari S (2002). Bioassay of nuclear polyhedrosis virus (NPV) and in combination with insecticide on Spodoptera litura (Fab). Omon Rice 10: 45-53.

40. Kumari V \& Singh NP (2002). Age related response of tobacco caterpillar, Spodoptera litura (Fabricius) (Lepidoptera: Noctuidae) to Biovirus-S, a commercial formulation of nuclear polyhedrosis virus. J of Biol Cont 16(2): 157-160.

41. Whitlock VH (1977). Effect of larval maturation on mortality induced by nuclear polyhedrosis and granulosis virus infections of Heliothis armigera. J Invertebr Pathol 30: 80-86.

42. Evans HF (1981). Quantitative assessment of the relationship between dosage and response of the nuclear polyhedrosis virus of Mamestra brassicae. J Invert Pathol 37: 101-109.

43. Kumar CS, Rao GR, Sireesha K \& Kumar PL (2011). Isolation and characterization of baculoviruses from three major lepidopteran pests in the semi-arid tropics of India. Indi J of Virol 22(1): 29-36.

44. Teakle, RE, Jensen JM \& Giles JE (1986). Age-related susceptibility of Heliothis punctigera to a commercial formulation of nuclear polyhedrosis virus. J Invert Pathol 36: 281-282.

45. Erlandson MA (2009). Genetic variation in field populations of baculoviruses, mechanisms for generating variation and its potential role in baculovirus epizootiology. Virologic Sinica 24: 458469.

46. Caballero P, Zuidema D, SantiagoAlvarez C \& Vlak, JM (1992). Biochemical and biological characterization of four isolates of Spodoptera exigua nuclear polyhedrosis virus. Biocont Sci Technol 2(2):145-157.

47. Vlak JM \& Gröner A (1980). Identification of two nuclear polyhedrosis viruses from the cabbage moth, Mamestra brassicae (Lepidoptera: Noctuidae). J Invertebr Pathol 35: 269278. 